\title{
KARTINI DAN POTRET PEREMPUAN INDONESIA MASA KINI (Sebuah Tinjauan Antropologis)
}

Oleh :

Siany Indria $\mathrm{L}^{1}$

\begin{abstract}
Abstrak
Pemahaman mengenai Kartini harus dilihat dalam konteks lebih satu abad yang lalu. Orang sering salah mengartikan dengan mengatakan bahwa cita-cita Kartini sudah berhasil. Perempuan sudah sejajar dengan laki-laki, paling tidak perempuan sudah boleh mengenyam pendidikan yang sama seperti laki-laki. Kartini sebagai sosok 'ibu' dengan identitas kultural Jawa yang melekat pada sosoknya. Yang menjadi urgensi adalah melihat bagaimana pemikiran dan gagasan Kartini tentang perempuan dan tentang pembebasan perempuan. Kartini jelas telah berusaha mendobrak tatanan kultur yang ada patriarkal meskipun negara telah menyembunyikannya sedemikian rupa. Apabila gagasan dan pemikiran Kartini didengungkan baik di tingkat pendidikan maupun dalam masyarakat luas maka yakinlah bahwa Kartini bisa tersenyum melihat perempuan-perempuan dan bangsa Indonesia yang kritis, berpemikiran tajam, lepas dari bentuk penjajahan yang dilakukan oleh kapitalisme dan neoliberal. Perempuan Indonesia akan menjadi Kartini baru, atau mungkin serupa dengan sosok Nyai Ontosoroh dalam novel tetralogi Pramoedya, perempuan yang kritis, tajam dan tak kenal ampun dengan kultur yang menindas perempuan.
\end{abstract}

Kata Kunci: Kartini, Perempuan, dan patriakal

${ }^{1}$ Staff Pengajar di Program Studi Pendidikan Sosiologi Antropologi, FKIP, Universitas Sebelas Maret (liestyasari2003@yahoo.co.uk ) 


\section{PENGANTAR}

Apa yang ada di benak kita tentang seorang Kartini? Apa yang terlintas di pikiran kita tentang seremonial hari Kartini yang kita peringati setiap tanggal 21 April di setiap tahunnya? Sungguhkah kita mengerti betul apa gagasan dan pemikiran Kartini tentang kaum perempuan dan bangsa Indonesia pada jamannya sehingga menggerakkanya untuk menulis beratusratus surat yang menguraikan kesedihannya tentang nasib bangsanya? Pernahkan kita membaca kumpulan suratnya kepada $\mathrm{Ny}$. R.M. Abendanon-Madri dan suaminya? Atau surat-surat yang lebih merupakan pemikiran Kartini terhadap sahabatnya Stella di Belanda? Kalau semua pertanyaan di atas terjawab dengan kata-kata belum dilakukan atau bahkan sama sekali tidak dilakukan, maka seperti apakah sebenarnya sosok Kartini dalam pemahaman kita? Bagaimana kita bisa mengatakan apakah pemikiran Kartini atau sosok Kartini menjadi suatu potret yang ideal bagi perempuan Indonesia masa kini di abad 21 yang konon kabarnya super canggih kalau kita belum mengetahui sedikitpun tentang sosok perempuan ini?

Paper singkat ini berusaha menganalisis sebuah pertanyaan yang ingin dijawab , yakni apakah Kartini potret perempuan ideal? Bukan hanya menanyakan kembali posisi Kartini baik sebagai pahlawan nasional maupun sebagai perempuan (Jawa) tapi sekaligus juga menguraikan kembali seperti apa kita mengenal sosok Kartini. Lebih jauh analisis akan ditekankan pada perspektif sosial kultural untuk melihat relevansi pemikiran Kartini dan potret dirinya di masa sekarang, khususnya berkaitan dengan kaum perempuan Indonesia. Analisis feminis akan diberikan untuk mempertajam pemahaman kita akan pemikiran Kartini dan relevansinya bagi perempuan dan masyarakat Indonesia masa kini.

\section{SEPERTI APA KITA MENGENAL KARTINI?}

Silahkan anda jawab pertanyaan saya di atas. Seperti apa kita mengenal sosok Kartini. Perempuan yang merupakan keturunan bangsawan di Jawa ini rupanya sangat terkenal. Selain diabadikan sebagai salah satu pahlawan nasional perempuan di Indonesia, namanya bahkan menjadi satu lagu nasional yang diciptakan oleh WR. Supratman dan didendangkan setiap tanggal 21 April pada saat upacara memperingati hari Kartini. Raden Ajeng (nama gelar, bukan nama depan) Kartini, mungkin hampir semua orang Indonesia pernah mendengar namanya. Tanggal kelahirannya diperingati secara semarak setiap tahunnya. Mungkin Kartini juga merupakan satu-satunya perempuan di Indonesia yang hampir semua anak yang bersekolah mengenal atau bahkan hapal 
lagu yang berjudul namanya. Tapi berapa banyak anak-anak Indonesia yang mengenal betul pemikiran dan gagasan Kartini? Mengapa Kartini begitu populer sementara masih banyak pahlawan nasional Indonesia lainnya yang berjenis kelamin perempuan juga berjuang membela tanah air pada jamannya?

Berdasarkan Keputusan Presiden No. 108 1964, Kartini ditetapkan sebagai Pahlawan Kemerdekaan Nasional, "dengan pertimbangan jasa-jasanya sebagai pemimpin Indonesia di masa silam yang semasa hidunya, karena didorong oleh rasa cinta Tanah air dan Bangsa memimpin suatu kegiatan yang teratur guna menentang penjajahan di muka bumi Indonesia" (Lasmina, 1998:64). Setelah Kartini dinobatkan sebagai pahlawan nasional, pada tahuntahun berikutnya negara mengadakan perayaan peringatan Hari Kartini dengan lebih mempopulerkan konsep-konsep keibuan yang pernah dicetuskan oleh Kartini. Diantaranya dengan kegiatan perayaan Hari Kartini di sekolah-sekolah melalui kompetisi atau kontes berkebaya, termasuk di dalamnya adalah. Hal-hal yang tidak pernah terbayangkan oleh Kartini bahwa hal itu justru terjadi di lembaga pendidikan yang dipercaya Kartini sebagai sarana awal pembebasan perempuan dari ketertindasan budaya. Satu hal yang mungkin membuat Kartini lebih populer dibandingkan pahlawan nasional perempuan Indonesia lainnya menurut dugaan saya adalah karena goresan penanya melalui surat-surat yang berisi kecaman terhadap adat, norma dan kondisi penjajahan yang membuat sengsara bangsanya. Kita tahu Kartini tidak punya senjata, dia juga tidak punya massa apalagi uang dan kekuasaan. Kartini hanya punya semangat yang dituliskannya dan dibaca banyak orang.

Namun selama hampir satu abad lebih setelah kematiannya kita tidak bisa menyangkal bahwa sosok Kartini yang ditanamkan oleh negara di benak masyarakat Indonesia adalah sosok keibuan yang "berjuang membela emansipasi perempuan pada jamannya". Kartini tetap tidak lepas dari sosok berkebaya, anggun - karena dia adalah golongan bangsawan maka terbiasa untuk bersikap dan berpakaian demikian pada jamannya-menurut pada ayah dan suaminya (gambaran tipikal perempuan Jawa pada umumnya) sekaligus cerdas dan berjiwa pemberontak (gambaran perempuan modern yang terkena imbas Eropa). Namun hal terakhir terkungkung dalam-dalam karena sistem feodalisme yang melingkupi kehidupannya. 
Gambaran "ibu” dalam diri Kartini sudah begitu melekat sehingga ketika orang membayangkan Kartini maka yang terlintas di benaknya adalah perempuan Jawa berkonde, berkebaya, halus tutur katanya, penurut, rela dipoligami dan sederet gambaran stereotipik perempuan Jawa di bawah payung ideologi patriarkal.

Atau banyak orang mengenal Kartini karena dianggap sebagai "pejuang nasib kaum perempuan di Indonesia”. Namun betulkah kita mengerti pemikiran dan gagasan Kartini tentang perjuangannya mengangkat bangsa Indonesia khususnya perempuan untuk keluar di belitan adat dan norma budaya yang membelenggunya? Kartini didefinisikan sebagai pahlawan tanpa kita tahu jelas bagaimana pemikirannya untuk bangsa Indonesia. Kita hanya mengenal sosoknya sebagai pembela nasib bangsa Indonesia dari penjajahan Belanda yang kemudian dia mengusahakan persamaan derajat antara laki-laki dan perempuan dengan berhaknya mereka mengenyam pendidikan tanpa memandang alasan apapun. Pendidikan dianggap Kartini sebagai alat pembebas dan alat yang bisa memerdekakan bangsanya. Di satu titik Kartini berhasil mewujudkan cita-citanya.

Namun sebetulnya lebih jauh dari itu semua. Artikel Lasmina (1998) berhasil memotret bagimana negara sebetulnya menyembunyikan gagasan pemikiran Kartini dan menggantikan ingatan masyarakat hanya pada sosok Kartini yang keibuan dan feminin. Padahal Kartini hadir dengan gagasan dan praktek pembebasan bukan hanya untuk perempuan tetapi juga untuk masyarakat terjajah. Cita-cita Kartini yang sesungguhnya tentang pembebasan perempuan dari keterbelengguan adat dan budaya patriarki hampir tidak pernah didengungkan. Tidak juga lewat film yang pernah dibuat tentang Kartini. Negara telah berhasil menyembunyikan gagasan dan pemikiran Kartini yang tertuang dalam surat-suratnya yang penuh kemarahan, jeritan hati, tentang perubahan status dan kondisi perempuan (bukan hanya perempuan Jawa dan ningrat). Negara juga membiarkan pemikiran dan gagasan Kartini menguap begitu saja. Gagasan yang sebenarnya pada perubahan nilai masyarakat yang memandang perempuan bukan sebagai warga negara. Pemikiran Kartini disembunyikan dari anak-anak sekolah mulai dari SD hingga SMA. Kita hanya mengenal sepintas sosoknya saja yang dijelaskan di bukubuku sejarah atau PPKN tanpa mengetahui lebih lanjut apa gagasan Kartini tentang pembebasan bagi perempuan. Kecuali mungkin hanya slogan bahwa perempuan berhak mengenyam pendidikan sama halnya dengan laki-laki. Yang disembunyikan 
negara adalah pemikiran dan gagasan Kartini tentang perempuan dan pembebasan perempuan,

Saya ingin bebas agar saya boleh, dapat berdiri sendiri, tidak perlu bergantung kepada orang lain, agar .... agar ... tidak harus kawin (Sutrisno, 1985:4).

Hampir semua perempuan yang saya kenal, mengutuk hak kaum lelaki itu. Tetapi mengutuk saja tidak ada gunanya. Harus ada tindakan. Maka mari ibu-ibu, perempuan-perempuan, gadis-gadis, bangkitlah, mari kita berbimbingan tangan dan bekerja sama untuk merubah keadaan yang tak tertahankan ini (Sutrisno, 1985:65).

\section{Gagasan Kartini tentang} pembebasan perempuan dari adat, norma dan agama yang membelit kehidupannya inilah yang selama ini disembunyikan. Indonesia baru mengenal wacana gender dan feminisme tak kurang sejak awal tahun 1990an padahal Kartini sudah lama mendengungkannya.

Uraian saya di atas sebetulnya adalah sosok Kartini yang seharusnya selama ini kita kenal. Sayang, berbagai rezim yang menguasai negara telah membuat citra Kartini hanya dikenal sebatas sebagai perempuan Jawa baik dengan busananya maupun dengan tutur katanya saja.

\section{KARTINI DAN PEREMPUAN \\ INDONESIA MASA KINI}

Dahulu, Kartini memberontak karena dia merasa adat, norma, budaya Jawa sekaligus keadaan dirinya sebagai perempuan membuatnya tidak bisa bergerak bebas. Dia harus menjalani pingitan selama 4 tahun. Berada dalam rumah yang dia sebut sebagai kurungan betapapun mewah dan megahnya kurungan itu. Kartini memberontak pada ketidakberdayaannya sebagai perempuan sekaligus anak yang tidak bisa melawan kehendak ayahnya. Cintanya pada sang Ayah membuatnya kalah dan menerima poligami, meskipun dia sendiri lahir dalam keluarga poligami. Adat Jawa yang feodal membuatnya sebagai perempuan tidak bisa melanjutkan sekolah sementara kakak laki-lakinya bebas meneruskan citacitanya ke HBS. Kartini tidak memberontak dengan berdemo namun dengan menuliskan nasib pahitnya pada kawannya yang orang Belanda.

Nasib Kartini yang demikian harus dilihat dalam konteks lebih satu abad yang lalu. Orang sering salah mengartikan dengan mengatakan bahwa cita-cita Kartini sudah berhasil. Perempuan sudah sejajar dengan laki-laki, paling tidak perempuan sudah boleh mengenyam pendidikan yang sama seperti laki-laki. Perempuan juga turut serta di sektor publik-bekerja-sama seperti laki-laki, 
dan lain sebagainya. Namun, betulkah itu yang sejatinya dicita-citakan Kartini? Apakah memperingati Kartini hanya sekedar dengan mengenakan kain panjang dan gelung serta menggelar berbagai lomba yang bertemakan 'perempuan' seperti memasak, merias wajah, memakai kain dan lainnya. Pandangan seperti itu rupanya menimbulkan rasa bangga bahwa kaum perempuan Indonesia sudah terlepas dari kungkungan, kaum perempuan sudah merdeka, dan sudah mengenyam pendidikan tinggi? Maka selesailah segala yang dipersoalkan sebagai persoalan perempuan. Saya cukup terkejut dengan pandangan semacam ini.

Kebudayaan masyarakat berubah seiring dengan perubahan jaman. Kalau dahulu yang dipersoalkan Kartini adalah pendidikan bagi perempuan maka Kartini mungkin akan tersenyum bangga melihat betapa banyaknya jumlah perempuan Indonesia yang mengenyam pendidikan tinggi, bisa baca tulis dan (baru-baru ini) terjun dalam dunia politik. Namun Kartini akan sangat sedih manakala mengetahui bahwa persoalan yang membelit perempuan Indonesia justru semakin kompleks. Kapitalisme yang juga bersekutu dengan ideologi patriarkal justru menyuburkan berbagai macam bentuk diskriminasi terhadap perempuan dewasa ini.

Ada banyak kasus-kasus human trafficking yang menjadikan perempuan sebagai korbannya. Perempuan, entah masih muda atau sudah berumur, entah itu dari desa atau kota, rentan terhadap tindak perdagangan manusia yang diawali dengan penipuan. Mereka dijadikan pembantu tanpa dibayar dan yang lebih sering dijadikan pekerja seksual. Kapitalisme juga membuat perempuanperempuan terjerat dalam industri seksual komersial dan pornografi. Semakin banyak anak-anak perempuan yang dilacurkan (AYLA). Belum lagi kasuskasus kekerasan terhadap perempuan yang menjelma dalam berbagai macam bentuk mulai dari KDRT (Kekerasan Dalam Rumah Tangga), eksploitasi dan kekerasan terhadap TKW dan buruh migran Indonesia di negara tetangga, perkawinan anak di bawah usia dan lain sebagainya.

Satu hal lain yang mungkin penting adalah persoalan kapitalisme. Kalau dahulu Kartini geram dengan kultur patriarkal yang membuatnya tak bisa menolak poligami, membuatnya tak mampu melawan feodalisme maka saat ini patriarki telah bercumbu dengan kapitalisme untuk mendiktekan gambaran perempuan ideal seperti yang diinginkan oleh patriarki. Berbagai pusat kecantikan didirikan dan banyak perempuan tanpa sadar mengikuti gambaran media tentang citra peremuan ideal. Tubuh yang ramping 
namun padat berisi, rambut panjang yang hitam legam, kulit putih mulus seelok pualam adalah serangkaian kriteria perempuan yang didiktekan oleh kapitalisme. Sinetron di televisi juga turut meneguhkan stereotipe bagaimana menjadi 'perempuan ideal' dalam konteks masa kini. Salah satu serial di televisi (Suami-Suami Takut Istri) misalnya yang telah menjungkirbalikkan citra perempuan menjadi sosok yang bengis, galak, egois, mau menang sendiri, cemburuan dan berotak dangkal. Tayangan semacam ini mungkin menjadi bahan lawakan namun justru sebenarnya meneguhkan status perempuan sebagai manusia yang didiktekan oleh patriarkal.

\section{PENUTUP: IDEALKAH KARTINI?}

Persoalan perempuan belum selesai sekalipun sudah seabad lebih Kartini meninggalkan kita. Yang perlu kita sadari sekarang adalah bukan saatnya melihat Kartini sebagai sosok 'ibu' dengan identitas kultural Jawa yang melekat pada sosoknya. Yang menjadi urgensi adalah melihat bagaimana pemikiran dan gagasan Kartini tentang perempuan dan tentang pembebasan perempuan. Saya sendiri masih menganggap bahwa sosok Kartini adalah sosok ideal untuk masa kini.
Kekritisan Kartini, ketajaman cara berpikirnya, rasa kasih sayangnya kepada perempuan dan bangsa Indonesia itulah yang harus didengungkan kepada bangsa ini. Kartini jelas telah berusaha mendobrak tatanan kultur yang ada patriarkal meskipun negara telah menyembunyikannya sedemikian rupa. Apabila gagasan dan pemikiran Kartini didengungkan baik di tingkat pendidikan maupun dalam masyarakat luas maka yakinlah bahwa Kartini bisa tersenyum melihat perempuanperempuan dan bangsa Indonesia yang kritis, berpemikiran tajam, lepas dari bentuk penjajahan yang dilakukan oleh kapitalisme dan neoliberal. Perempuan Indonesia akan menjadi Kartini baru, atau mungkin serupa dengan sosok Nyai Ontosoroh dalam novel tetralogi Pramoedya, perempuan yang kritis, tajam dan tak kenal ampun dengan kultur yang menindas perempuan. Selamat Hari Kartini. 


\section{DAFTAR PUSTAKA}

Lasmina, Umi. (1998). “Jangan Sembunyikan Kartini” dalam Jurnal Perempuan Edisi 06 Februari - April. Halaman 63 - 68. Jakarta: Yayasan Jurnal Perempuan.

Rahayu, Ruth Indiah. (2003) "Sebuah Epilog: Kartini di Akhir Abad 20: Sebuah Relikwi atau Insirasi” dalam Pramoedya Ananta Toer Panggil Aku Kartini Saja. Jakarta: Lentera Dipantara.

Sutrisno, Sulastin. (1985) Kartini: Surat Kepada NY. R.M. Abendanon dan Suaminya. Jakarta: Djambatan.

Toer, Pramoedya Ananta. (2003). Panggil Aku Kartini Saja. Jakarta: Lentera Dipantara. 